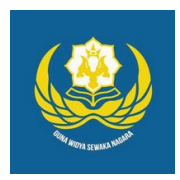

Jurnal Analogi Hukum

Journal Homepage: https://ejournal.warmadewa.ac.id/index.php/analogihukum

\title{
Penguasaan Hak Atas Tanah Oleh Orang Asing Berdasarkan Perjanjian Pinjam Nama (Nominee)
}

\author{
I Wayan Pebriyana*, I Nyoman Putu Budiartha dan I Putu Gede Seputra \\ Universitas Warmadewa, Denpasar-Bali, Indonesia \\ *iwayanpebriyana@gmail.com
}

\begin{abstract}
How To Cite:
Pebriyana, I, W., Budiartha, I, N, P., Seputra, I, P, G. (2020). Penguasaan Hak Atas Tanah Oleh Orang Asing Berdasarkan Perjanjian Pinjam Nama (Nominee). Jurnal Analogi Hukum. 2 (3). 326-330. Doi: https://doi.org/10.22225/ah.2.3.2509.326-330

Abstract-The use of a nominee agreement was the embodiment of the existence of an Alliance. Embodiment of the nominee is on the letter of the agreement made by FOREIGNERS and CITIZENS as the giver of power, the agreement was intended to give the authority against a FOREIGN NATIONAL as a recipient of the power of the law against doing in respect of land that cannot be He owns that is proprietary. There are two problems in research, namely: (1) the mechanism of the mastery of land rights by foreigners, (2) the power of the law of the Dominion land rights based on loan agreement name (Nominee). The goal of research to understand the mechanisms of domination the land rights committed by foreigners and to know the legal power of the Dominion land rights by foreigners on the basis of the Covenant borrow names (nominee). Research methods used normative legal research library or study of the positive law in force. Based on the research note that: (1) mastery of land rights by FOREIGNERS is done with usage rights and the right of rental, and the existence of an agreement borrowed the name, the name of WNI noted in the certificate property. (2) The force of law pernjanjian borrowed the name seen from Article 1 Paragraph Burgerlijk Wetboek 1338, any agreement made legally valid as legislation.
\end{abstract}

Keywords: Nominee Agreement; Mastery of Land Right; Law Strength

\begin{abstract}
Abstrak-Penggunaan perjanjian nominee yang merupakan perwujudan adanya suatu perikatan. Perwujudan nominee ada pada surat perjanjian yang dibuat oleh WNA dan WNI sebagai pemberi kuasa, dalam perjanjian itu bermaksud untuk memberikan kewenangan terhadap WNA selaku penerima kuasa dalm melakukan perbuatan hukum terhadap tanah yang tidak dapat dimilikinya yaitu hak milik. Ada dua masalah dalam penelitian, yaitu: (1) Mekanisme penguasaan hak atas tanah oleh orang asing, (2) Kekuatan hukum penguasaan hak atas tanah berdasarkan perjanjian pinjam Nama (Nominee). Tujuan penelitian untuk memahami mekanisme penguasaan hak atas tanah yang dilakukan oleh orang asing dan untuk mengetahui kekuatan hukum dari penguasaan hak atas tanah oleh orang asing berdasarkan perjanjian pinjam nama (nominee). Metode penelitian menggunakan penelitian hukum normatif dari studi pustaka atau hokum positif yang berlaku. Berdasarkan penelitian diketahui bahwa: (1) Penguasaan hak atas tanah oleh WNA dilakukan dengan hak pakai dan hak sewa, dan adanya suatu perjanjian pinjam nama, nama WNI dicantumkan di sertifikat hak milik. (2) Kekuatan hukum pernjanjian pinjam Nama dilihat dari Pasal 1338 Ayat 1 KUHPerdata, setiap perjanjian dibuat secara sah berlaku sebagai Undang-undang.
\end{abstract}

Kata Kunci: Perjanjian Nominee; Penguasaan Hak Atas Tanah; Kekuatan Hukum

\section{Pendahuluan}

Sebagai Negara yang berkembang di dunia, Indonesia ialah Negara kepulauan yang akan kekayaan alamnya yang sangat diakui dunia dan warga Negara asing khususnya investor banyak yang tertarikuntuk menanamkan modalnya dalam bidang pertanahan (Harsono, 2003). Warga Negara asing yang datang ke Indonesia bertujuan untuk menikmati keindahan alamnya dan tidak sedikit warga Negara asing ke Indonesia juga ingin berinvestasi.

UUPA menyebutkan bahwa hak milik atas tanah yang dapat dikuasai oleh WNI sementara WNA termasuk perwakilan perusahaan asing Cuma bisa memiliki hak atas tanah yang bersifat terbatas dan tidak mengganggu kepentingan warna warga negara indonesia. Berdasarkan Pasal 22 Undang-Undang Nomor 5 
Tahun 1960 tentang Peraturan Dasar PokokPokok Agraria, yang lazim juga disebut Undang -Undang Pokok Agraria, yang untuk selanjutnya disebut UUPA, dapat diketahui bahwa hak milik atas tanah dapat terjadi melalui tiga cara, yaitu; (1) berdasarkan undang-undang, (2) berdasarkan penetapan pemerintah, dan (3) berdasarkan hukum adat (Ismail, 2012). Prinsip nasionalitas dalam kepemilikan tanah seperti di atas tidak terlepas dari perumusan konsep hak milik yang relative (Parlindungan, 1993).

UUPA menyatakan bahwa Hanya WNI yang dapat mempunyai hubungan sepenuhnya dengan bumi, air dan ruang angkasa. Dalam hal ini dikatakan hanya Warga negara Indonesia saja yang dapat menjadi subjek hak milik, sedangkan Warga Negara Asing hanya mempunyai hak sewa dan hak pakai saja. Penguasaan tanah milik perorangan oleh pemerintah atau negara merupakan suatu kewenangan yang dimiliki pemerintah berdasarkan ketentuan pada Pasal 33 Undang-Undang Dasar Republik Indonesia tahun 1945 (selanjutnya disebut UUD 1945) (Buana \& Marwanto, 2018).

Undang-undang yang memuat penguasaan hak atas tanah dalam kegiatan sewa menyewa oleh WNA di Indonesia cukup memadai, namun masih banyak celah yang bisa dimanfaatkan oleh WNA dalam menguasai tanah tanah di Bali, yaitu dengan meminjam nama WNI. Dalam hal ini WNA dan WNI mengikatkan diri dengan sebuah perjanjian seperti akta pengakuan hutang. Tindakan seperti ini dikenal sebagai nominee, agar WNA dapat mempunyai hak secara penuh.

Adanya asas nasionalisme yang di miliki di Indonesia. Terkait dengan inventarisasi di awal jenis akta dibuatnya di depan notaris oleh warga negara asing dengan maksud memperoleh kepemilikan atas tanah dari warga negara indonesia adalah melalui instrumen perundangan yang berlaku seperti hak pakai, hak guna banguanan, hak atas tanah, akta pengakuan hutang juga dikenal sebagai tindakan nominee ini dengan tujuan agar WNA dapatmemiliki hak secara penuh.

Perjanjian yang tidak diatur dalam Kitab Undang-Undang Hukum Perdata namun timbul, tumbuh dan berkembang di masyarakat yaitu disebut Perjanjian nominee. Berdasarkan peraturan perundangan yang berlaku, Perjanjian nominee harus berada di bawah peraturan hukum perjanjian dalam Peraturan Perundangan tentang Perikatan.

Perwujudan adanya suatu perikatan disebut penggunaan perjanjian nominee. Menurut peraturan perundangan yang berlaku tercantum perikatan dilahirkan baik karena persetujuan, baik karena undang-undang. Perundangan yang berlaku tertulis bahwa setiap perjanjian adalah untuk memberikan sesuatu, untuk berbuat sesuatu, dan atau untuk tidak berbuat sesuatu. Kesepakatan yang semestinya dilakukan oleh keduabelah pihak terkait yang tercantum dalam syarat sahnya perjanjian yang diatur dalam suatau perjanjianyang dibuatnya yang berlaku oleh karena itu, disebut perjanjian.

latar belakang masalah tersebut di atas dapat dirumuskan permasalahan sebagai berikut :

Bagaimana mekanisme penguasaan hak atas tanah oleh orang asing?

Bagaimana kekuatan hukum penguasaan hak atas tanah berdasarkan perjanjian pinjam Nama (nominee)?

Secara umum penelitian ini dilakukan untuk mengetahui penguasaan hak atas tanah oleh orang asing berdasarkan perjanjian pinjam $\mathrm{Na}$ ma (nominee) sesuai dengan peraturan perundang-undangan yang mengaturnya sedangkan khususnya penelitian ini bertujuan untuk:

Untuk memahami mekanisme penguasaan hak atas tanah yang dilakukan oleh orang asing.

Untuk mengetahui kekuatan dari penguasaan hak atas tanah oleh orang asing berdasarkan perjanjian pinjam Nama (nominee).

\section{Metode}

Tipe Penelitian yang digunakan dalam penelitian ini menggunakan metode hukum normatif yang bertujuan untuk meneliti kepastian hukum berpacu hasil dari kepustaka atau hukum yang berlaku.Tipe Permasalah yang dimuat ialah melalui perundang-undang yaitu dengan memuat semua pendekatan yang berkaitan dengan isu hukum yang ditangani. Untuk memecahkan isu hukum yang ada maka diperlukan sumber bahwa hukum yang langsung diperoleh dilapangan melalui wawancara, bahan hukum dari teori-teori dan konsep serta bahan yang diperoleh melalui kamus-kamus hukum. Teknik pengumpulan hasil penelitian tersebut dapat disajikan secara sistematis berdasarkan peraturan yang dimuat dengan realita yang ada di lapangan/masyarakat.

\section{Hasil Penelitian Dan Pembahasan}

\section{Mekanisme Penguasaan Hak Atas Tanah Oleh Orang Asing}


Definisi "penguasaan" dan "menguasai" yang digunakan dalam arti fisik dan yuridis. Boedi Harsono, penguasaan secara yuridis didasari pada hak yang dilindungi hukum dan secara umum memberikan kewenangan terhadap pemegang hak untuk menguasai secara fisik atas tanah yang dihaki. Namun ada juga penguasaan secara yurudis, meskipun memberi kewenangan kepada pemegang hak untuk menguasai secara fisik namun pada kenyataannya penguasaan fisiknya dilakukan pihak lain (Harsono, 2003).

Orang luar negeri dalam hal ini bukan warga negara Indonesia yang sering disebut warga negara asing apabila berkeinginan mempunyai tanah dan atau rumah diatasnya, hanya boleh melalui lembaga yang disebut hak pakai dimana orang tersebut boleh memiliki tanah atau rumah diatur dalam peraturan perundangan seperti peraturan pemerintah No 1 Tahun 1996 tentang kepemilikan rumah tempat tinggal atau bangunan bagi orang bukan orang Indonesia asli yang berkeinginan bertempat tinggal di Indonesia yaitu Hak Pakai bagi warga negara asing. Orang asing bisa memiliki rumah yang dijadikan sbeagai tempat tinggal dengan menggunakan hak atas tanah tertentu (Pada Pasal 1 ayat 1). Hak Pakai juga terbagi menjadi Hak Pakai atas tanah milik pemerintah dan hak pakai atas tanah dengan berdasarkan suatu kesepakatan. Dimana kepemilikan dari tanah berdasarkan kesepakatan tersebut berlaku hanya 25 (dua puluh lima) tahun, apabila ada kecocokan atau kesepakatan antara pemilik dengan orang yang menyewa dan orang tersebut adalah warga negara Indonesia bukan asing.

Jikalau orang/penyewa tanah atau bangunan tersebut sudah tidak lagi berada di Indonesia dalam waktu atau Selama kurang lebih 1 (satu) tahun tanah atau bangunan tersebut harus dilepaskan atau diberi orang lain yaitu warga negara Indonesia yang sudah memiliki persyaratan. Dimana rumah tersebut akan dilelang atau dijual apabila tanah atau bangunan tersebut didirikan atas kesepakatan atau perjanjian, maka tanah atau bangunan tersebut dalam tempo waktu 1 tahun belum juga dilepaskan atau diambil alih hak tanah atau bangunan tersebut menjadi milik negara Indonesia.

Seperti contoh hubungan hukum antara orang Indonesia asli sebagai pemilik tanah atau bangunan dengan orang luar bukan warga negara Indonesia atau orang asing, kepemilikan dari bangunan atau tanah tersebut bisa saja berbuntut suatu kesepakatan atau perjanjian sewa menyewa, biasanya kesepakatan atau perjanjian sewa menyewa itu apabila berjangka panjang, harus ditetapkan/dicantumkan dalam perjanjian atau kesepakatan secara pasti apakah 25 (dua puluh lima) tahun ataukah 30 (tiga puluh) tahun, jadi harus ada kepastian (M. S. W. Sumardjono, 2008).

Ketentuan kepastian batas waktu kesepakatan atau perjanjian hak pakai aatas tanah atau hak sewa menyewa atas tanah atau bangunan tersebut adalah sebagai suatu sebab yang melatar belakangi dilakukannya kesepakatan pinjaman nama sebagai bentuk kepemilikan atas tanah atau bangunan oleh orang asing. Karena kalau hanya berdasarkan kesepakatan atau perjanjian sewa menyewa hanya berlaku 25 tahun dan dapat diperpanjang $2 \mathrm{kali}$, ini membuat pihak luar atau orang asing teresebut sering memakai istilah no name yaitu memakai nama orang Indonesia asli dengan memperoleh imbalan baik berupa uang, benda atau kepemilikan jika orang luar atau orang asing tersebut sudah kembali ke negaranya.

Dilapangan sering terjadi bahwa tanah atau bangunan sebenarnya milik orang luar atau warga negara asing, tetapi di serttifikat tanah tersebut atas nama orang Indonesia asli. Orang ini biasanya dipercaya mengurus mulai dari pensertifikatan, membangun sampai dengan mengoperasikan property tersebut atas nama orang kepercayaannya dan sebagai pengaman bagi WNA, WNI yang namanya digunakan sebagai orang yang secara hukum memiliki tanah atau properti tersebut menandatangani surat pernyataan pengakuan bahwa tanah atau properti tersebut bukanlah miliknya dan namanya hanya dipinjam.

Melalui perjanjian notariil, telah terjadi penyelundupan hukum maka perjanjian pokok yang diikuti dengan perjanjian lain terkait penguasaan hak atas tanah oleh warga negara asing menunjukkan bahwa secara tidak langsung menurut Maria SW. Sumardjono (M. S. Sumardjono, 1994).

Pemalsuan surat-surat merupakan suatu upaya yang bertujuan mengelabui pelanggaran hukum nasional dalam hal ini undang-undang keagrariaan sehingga orang tersebut mendapatkan laba atau keuntungan sesuai dengan yang dikehendaki. Hal tersebut telah diuraikan sebelumnya, bahwa warga negara asing atau pihak luar bukan warga negara Indonesia dilarang untuk memiliki tanah sebagai hak milik atas tanah atau bangunan, termasuk dalam hal peralihan ha katas tanah melalui proses jual beli, tukar menukar, pewarisan, perwakapan dan bahkan wasiat atau hal-hal lain yang bertujuan untuk memindahkan hakatas tanah atau bangunan tersebut kepada pihak luar bukan orang Indonesia. 
Mengatasnamakan tanah atau bangunan dalam sertifikat atas nama sendiri tapi kenyataannya milik orang luar atau orang asing disebut nominee bahwa kepemilikan tanah atau bangunan tersebut adalah milik orang asing tapi dalam sertifikat atas nama orang Indonesia yang dipercaya oleh orang asing tersebut untuk mengurusi, mengelola tanah atau bangunan tersebut sebagaimana miliknya sendiri, padahal milik orang asing tersebut, hanya orang asing tersebut meminjam nama saja (M. Sumardjono, 2005).

Sesuai dengan hukum di Indonesia, maka kesepakatan atau persetujuan pinjam meminjam nama dapat dikategorikan sebagai perjanjian innominaat hal tersebut telah dijelaskan diatas bahwa suatu kesepakatan/persetujuan dikatagorikan sebagai suatu perjanjian tidak bernama apabila perjanjian tersebut bukan diatur dalam peraturan perundang-undangan di Indonesia seperti KUHP maupun KUHPerdata namun persetujuan/kesepakatan tersebut tumbuh dan berkembang di dalam masyarakat, walaupun persetujuan atau kesepakatan belum diatur belum ada yang mengatur secara khusus dan tegas.

\section{Kekuatan Hukum Penguasaan Hak Atas Tanah Berdasarkan Perjanjian Pinjam Nama (Nominee)}

Dikenal dengan istilah perjanjian nominee yaitu hak memiliki yang ditujukan terhadap hak dimana suatu kuasa yang sebenarnya dimana wewenang untuk melakukan perbuatan hukum dimana layaknya orang yang memiliki hak. pengelolaandalam hak milik atas tanah berisi hak pakaiyang luas, bahkan hak menguasai atas tanah lebih tinggi dari pada hak atas tanah Menurut Oloan Sitorus (Sitorus, 2004).

Adapun kekuatan hukum dilihat dari mengikatnya suatu perjanjian ini terletak pada komitmen di antara para pihak di dalam perjanjian tersebut, yaitu selama tidak ada pengingkaran oleh para pihak terhadap apa yang telah disepakati dan dinyatakan di dalamnya. Walaupun demikian dengan adanya struktur perjanjian nominee yang didalamnya ada perjanjian sewa menyewa maka kepentingan WNA dalam penguasaan atas tanahnya tetap terlindungi. Jadi perjanjian nominee ini dibuat untuk menjadi sarana dalam berinvestasi bagi orang asing dan untuk menjaga komitmen para pihak dalam rangka untuk kelangsungan usahanya. Dengan adanya perjanjian tersebut, maka yang dapat memberikan kepastian hukum dalam penguasaan tanah untuk investor, yaitu adanya kesempatan untuk menggunakan bidang tanah yang dikuasainya, selama diperlukan untuk memperoleh manfaat yang wajar dari investasinya. Atas dasar itulah, apabila terjadi sengketa antar pihak, maka dapat dijadikan pertimbangan untuk memberikan perlindungan hukum bagi WNA yang telah menanamkan modalnya dalam berinvestasi. Dengan ini melindungi hukum terhadap hak atas tanah yang dimiliki, yaitu melindungiatas hubungan hukumnya dan menjamin terhadap pelaksanaan kewenangan haknya.

Menurut pendapat penulis adapun perjanjian dibuat oleh para pihak dan dengan memuat aturan tetap sah dimata hukum, jadi untuk kekuatan hukum WNA sebagi nominee, penulis melihat dari ketentuan peraturan perundangan yang berlakusetiap perikatan yang dibuat secara sah berlaku bagi mereka yang membuatnya.

\section{Simpulan}

Berdasarkan uraian tersebut diatas dapatlah ditarik simpulan sebagai berikut:

Mekanisme penguasaan hak atas tanah oleh orang asing di Indonesia hanya dapat dilakukan dengan hak pakai dan hak sewa atas tanah di Indonesia. Biasanya jenis hak pakai dan hak sewa ini berjangka atau terbatas waktu yang harus ditentukan dalam akta perjanjian sewa-menyewa itu. Jadi jenis hak pakai dan hak sewa itu berjangka waktu, maka dilakukanlah perjanjian nominee, perjanjian ini timbul, tumbuh dan berkembang di masyarakat. Dalam perjanjian nominee inilah cara orang asing menguasai tanah di Indonesia, perjanjian ini tidak ada dalam KUHPerdata, perjanjian ini merupakan perwakilan atau meminjam nama orang Indonesia dengan mencantumkan nama WNI tersebut di sertifikat hak milik, berdasarkan perjanjian yang dibuat oleh WNA dan WNI. Dalam suratkuasa tersebut berisi pernyataan WNI bahwa tanah tersebut namanya telah dipinjam oleh WNA untuk dicantumkan dalam sertifikat tersebut.

Kekuatan hukum perjanjian pinjam nama yang dilakukan oleh WNA tersebut dilihat dari syarat sahnya perjanjian dan asas kebebasan berkontrak yang menyatakan semua perjanjian yang dibuat secara sah berlaku bagi mereka yang membuatnya, perjanjian ini mengikat halhal dimana dinyatakan dalam perikatan tersebut. Dimana adanya struktur perjanjian nominee yang didalamnya ada perjanjian sewa menyewa maka kepentingan WNA dalam penguasaan atas tanahnya tetap terlindungi.

\section{Daftar Pustaka}

Buana, A. A. S. T., \& Marwanto. (2018). Pengaturan Hak Penguasaan Tanah Hak 
Milik Perorangan Oleh Negara. Law

Reform. Retrieved from https:// ocs.unud.ac.id/index.php/Kerthanegara/ article/download/33157/20022

Harsono, B. (2003). Menuju penyempurnaan Hukum Tanah Nasional. Jakarta: Trisakti.

Ismail, I. (2012). Kajian terhadap Hak Milik atas Tanah yang Terjadi Berdasarkan Hukum Adat. Kanun Jurnal Ilmu Hukum, 56. Retrieved from http:// www.jurnal.unsyiah.ac.id/kanun/article/ download/6196/5092

Parlindungan, A. . (1993). Komentar A tas Undang-Undang Pokok Agraria. Bandung: Mandar Maju.

Sitorus, O. (2004). Kapita Selekta Perbandingan Hukum Tanah, Mitra Kebijakan Hukum Tanah Indonesia. Jakarta.

Sumardjono, M. (2005). Kebijakan Pertanahan Antara Regulasi dan Implementasi. Jakarta: Kompas.

Sumardjono, M. S. (1994). WNA dan Pemilikan Hak Milik Terselubung. Jakarta: Kompas.

Sumardjono, M. S. W. (2008). Alternatif Kebijakan Pengaturan Hak atas Tanah beserta Bangunan bagi Warga Negara Asing dan Badan Hukum Asing. Jakarta: Kompas. 